учнів, стимулює потребу в набутті певної системи вмінь і навичок, прагнення до професійного самовдосконалення.

\title{
Література
}

1. Духнович А. В. Народная педагогика в пользу училищ и учителей сельских. Ч. 1. / А. В. Духнович. - Львов, 1857. - 92 с. 2. Концепція громадянського виховання особистості в умовах розвитку української державності // Педагогічна газета. - 2000. - № 6. - С. 4-6. 3. Мороз О. Г. Підготовка майбутнього вчителя: зміст та організація : [навч. посібн.] / О. Г. Мороз, В. О. Сластьонін, Н. І. Філіпченко. - Київ, 1997. - 168 с. 4. Савченко О. Я. Виховний потенціал початкової освіти / О. Я. Савченко. - Київ : СПД «Цунзинович Т. І.».2007. - 204 с. 5. Сухомлинський В. О. Вибрані твори: у 5 т. / В. О. Сухомлинський. - Київ : Рідна школа, 1977. - Т. 5. - С. 393-628. 6. Сухомлинський В. О. Вибрані твори: у 5 т. / В. О. Сухомлинський. - Київ : Рідна школа, 1977. - Т. 4. - С. 311. 7. Троцко Г. В. Теоретичні питання формування професійно-педагогічної готовності майбутнього вчителя / Г. В. Троцко. - Харків : «ОВС», 2002. - Ч. 1. - 201 с.

УДК 614.8(078.8)

Лариса Семенець

\section{МЕТОДОЛОГІЧНИЙ АСПЕКТ ФОРМУВАННЯ ПРОФЕСІЙНО-ПЕДАГОГІЧНОЇ ГОТОВНОСТІ ДО НАВЧАННЯ УЧНІВ ОСНОВАМ ЗДОРОВ'Я}

Семенець Л. М. Методологічний аспект формування професійно-педагогічної готовності до навчання учнів основам здоров'я.

У роботі з позицій діяльнісного, системного, комплексного, особистісно зорієнтованого, антропологічного, культурологічного, акмеологічного та компетентнісного підходів проаналізовано особливості формування професійної готовності майбутніх учителів до навчання учнів основам здоров’я.

Ключові слова: науковий підхід, готовність, професійно-педагогічна готовність, основи здоров’я.

Семенец Л. Н. Методологический аспект формирования профессиональнопедагогической готовности к обучению учащихся основам здоровья.

В работе с позиций деятельностного, системного, комплексного, личностно ориентированного, антропологического, культурологического, акмеологического и компетентностного подходов проанализированы особенности формирования профессиональной готовности будущих учителей к обучению учащихся основам здоровья.

Ключевые слова: научный подход, готовность, профессионально-педагогическая готовность, основы здоровья.

Semenets L. M. Methodological aspect of formation of professional and pedagogical readiness for students' training of basics of health.

In the article the features of professional readiness formation of future teachers for students' training of basics of health from the activity, system, comprehensive, person-centered, anthropological, cultural, acmeological and competence based approaches have been analysed.

Key words: scientific approach, readiness, professional and pedagogical readiness, basics of health. 
Підготовка висококваліфікованих і компетентних спеціалістів, процес формування випускників вищих навчальних закладів як суб’єктів професійної діяльності перебувають у тісному взаємозв'язку з професійною готовністю - однією з центральних проблем сучасних психолого-педагогічних досліджень.

Сучасний розвиток України вимагає подальшого вдосконалення системи підготовки вчителя як особистості, здатної ставити та вирішувати важливі й необхідні завдання щодо проблем безпеки, які постають перед загальноосвітньою школою на якісно новому рівні. Учитель як гарант збереження життя й здоров'я дітей повинен не тільки вміти створювати безпечні, комфортні та результативні умови навчально-виховного процесу, а й формувати в учнів культуру безпеки - озброїти учнів необхідними знаннями, уміннями й навичками 3 безпеки життєдіяльності [10].

Важливість зазначеної проблеми привертає увагу до неї науковців та педагогівпрактиків, що мають безпосереднє відношення до викладання безпеки життєдіяльності у вищих навчальних закладах. Заслуговують на увагу дослідження С. Гвоздій, В. Зацарного, В. Заплатинського, О. Запорожця, Г. Кондрацької, Є. Логвінової, А. Свириденко, Л. Сидорчук та ін. Проте, незважаючи на збільшення кількості наукових публікацій із проблеми дослідження, понятійний апарат, що характеризує сутність наукових підходів у професійно-педагогічній освіті, майбутні фахівці не завжди уявляють, як можна реалізовувати наукові підходи у процесі вивчення «Основ здоров’я».

Мета статmі- виокремити й обгрунтувати наукові підходи до формування професійної готовності до навчання учнів основам здоров’я.

Методологічний рівень розв'язання проблеми професійно-педагогічної готовності до навчання учнів основам здоров'я передбачає застосування діяльнісного, системного, комплексного, культурологічного, особистісно зорієнтованого, акмеологічного та компетентнісного підходів у змісті професійно-педагогічної підготовки.

Відповідно до діяльнісного підходу процес формування професійної готовності майбутніх учителів здійснюється разом 3 етапами засвоєння навчально-педагогічної діяльності. Як висновок, педагогічні знання та вміння слугують підсистемою структури дій, а їх якість забезпечується повноцінною діяльністю, що виконується відповідно до визначеної етапності.

У процесі формування професійно-педагогічної готовності необхідно дотримуватися концептуального положення про те, що знання ніколи не можна дати в готовому вигляді. Вони завжди засвоюються через включення їх до тієї чи тієї діяльності [13, с. 257]. Нам імпонує думка українських науковців П. Олійника та С. Гончаренка: «Знання, уміння і спосіб мислення не можна передати в готовому вигляді, вони формуються лише в процесі розумової і практичної діяльності» [6, с. 41]. Тому процес формування професійної готовності майбутніх учителів передбачає не ретрансляцію наукових знань, їх засвоєння і відтворення, а розвиток особистісних утворень в умовах повноцінної навчально-педагогічної діяльності.

Розв'язання поставленої проблеми забезпечується принципово іншою дидактичною моделлю організації навчального процесу. Концептуальною ідеєю слугує положення про те, що знання та професійні вміння мають бути результатом виконаної діяльності, а повноцінне формування професійно-педагогічної готовності передбачає відмову від традиційно усталеної лінійної дидактичної схеми: теорія $\Leftrightarrow$ практика $\Leftrightarrow$ знання $\Leftrightarrow$ контроль і оцінка.

Розроблення концептуальної моделі професійно-педагогічної готовності, обгрунтування теоретичних основ формування професійної готовності майбутніх учителів до 
реалізації розвивальної функції навчання [11, с. 62-104] здійснюється на основі системного підходу, згідно з яким всяке особистісне утворення, процес чи явище розглядається як система - складний за своєю організацією об’єкт, що має компоненти, характеризується цілісністю і структурою. Цілісність, як одна із головних ознак системи, передбачає принципову незвідність властивостей систем до сукупності властивостей її елементів, а також залежність властивостей кожного компонента від його місця та функцій у системі [12, с. 86].

Реалізація системного підходу в освітній теорії та практиці- одне із ключових завдань психолого-педагогічних досліджень. Ми апелюємо до думки С. Рубінштейна 3 приводу того, що оскільки все в реальному світі системно, то й знання, які описують різноманітність його форм, мають бути системними [9, с. 259]. 3 огляду на системний підхід професійно-педагогічна готовність - це складне системне утворення, що має дворівневу структуру, характеризується низкою структурних компонентів (підсистем), визначається характером зв’язків між підсистемами, а також між системою та кожним із її компонентів.

Такий підхід до вивчення професійної готовності спрямований на розкриття цілісності педагогічних об'єктів, виявленні в них різноманітних типів зв'язків і зведення їх у єдину теоретичну картину [4]. Створена теоретична картина виконує роль моделі - цілком певної системи професійно-педагогічної готовності студентів, яка, як зазначає В. Штофф, відображає й відтворює об’єкт дослідження та здатна замінити його так, щоб вивчення побудованої системи дало нову інформацію про об’єкт пізнання [14, с. 19].

Розроблена нелінійна модель професійно-педагогічної готовності студентів, складність процесу формування професійної готовності майбутніх учителів до навчання учнів основам здоров'я зумовлюють розгляд названого системного утворення в контексті законів синергетики. Реалізація синергетичної парадигми передбачає кілька альтернативних шляхів розвитку складних систем. Уважаємо, що варіативність та альтернативність процесу формування професійно-педагогічної готовності забезпечується її особистісним рівнем, актуалізацією одного чи кількох вимірів особистості: генетичного, діяльнісного, соціальнопсихолого-індивідуального. Ключову роль у цьому процесі відіграє особистість викладача, його ціннісні орієнтації, професійно-педагогічна діяльність, педагогічні та спеціальні (фахові) здібності, парадигмальне мислення, педагогічна спрямованість на співпрацю й співробітництво в умовах міжособистісних відносин. У контексті синергетичного підходу професійна готовність майбутніх учителів - це складна дворівнева система як цілісна єдність структурних компонентів функціонального та особистісного рівнів, напрям саморозвитку цієї системи визначають особистісні виміри як студента, так і викладача.

У процесі професійної підготовки майбутніх учителів 3 основ здоров'я мають дотримуватися основні положення синергетичної парадигми освіти: 1) навчання - це не передача готових знань, а співпраця, діалогово-комунікативна взаємодія учасників навчально-виховного процесу; 2) педагогічному процесу як складній відкритій системі не можна нав’язувати ззовні лінійні шляхи розвитку, керувати такою системою найефективніше із середини в умовах міжособистісних відносин; 3) у навчально-виховному процесі має передбачатися, моделюватися, проектуватися та реалізовуватися декілька альтернативних шляхів розвитку особистості; 4) визначальним $є$ не сила педагогічної дії, а ії наявність і правильна структурованість у педагогічному процесі [3, с. 5].

Антропологічний підхід дозволяє проаналізувати еволюцію взаємодії людини, природи, суспільства в історичному, соціальному, біологічному контекстах [7, с. 10]. Одним iз концептуальних є положення про те, що формування професійної готовності майбутніх 
учителів до навчання учнів основам здоров'я здійснюється завдяки присвоєнню суспільно відпрацьованих способів мислення та діяльності. Оскільки, згідно з ученням Л. Виготського, усі психічні властивості людини мають культурно-історичне походження [1, с. 488], то джерелом формування та розвитку складних особистісних утворень є культура. І. Зязюн доводить, що культурологічний підхід змінює уявлення людини про основоположні цінності як виключно інформаційно-знаннєві, знімає вузьку наукову орієнтованість їі змісту i принципів побудови навчального плану, розширює культурні основи змісту навчання i виховання, вводить критерії творчості в діяльність педагога і студента [2, с. 7].

На нашу думку, процес формування професійної готовності майбутніх учителів має проходити в умовах висококультурного освітнього середовища, в якому поєднуються професіоналізм і культурна освіченість, творчість і відповідальність за результати діяльності. Беззаперечною є теза про те, що культурологічний підхід піднімає рівень об’єктивності здобутих даних, оскільки педагогічний процес, вивчений у контексті соціокультурних характеристик, дозволяє виявити й простежити тенденції в динаміці його цілей, зумовлених розвитком ціннісних орієнтирів соціуму [8, с. 80].

У зв’язку з цим професійна підготовка педагога має відбуватися в межах ключового чинника особистісного розвитку - формування загальнолюдської й професійно-педагогічної культури. Однією з головних професійних вимог до викладача як суб’єкта культури є володіння технологією інноваційної педагогічної діяльності, спрямованої на розвиток особистісних утворень майбутніх учителів.

Особистісно зорієнтований підхід розкриває професійну готовність як складне особистісне утворення, багаторівневу систему особистісних якостей, властивостей і станів, що забезпечують успішну професійну діяльність, дозволяють бути їі суб’єктом. Зауважимо, що на сучасному етапі модернізації освітньої галузі одним з першочергових завдань $\epsilon$ розроблення шляхів і способів реалізації особистісно зорієнтовного підходу, актуалізації особистісних і діяльнісних чинників у професійно-педагогічній освіті.

Філософські ідеї про діалектичну єдність загального, особливого й одиничного втілюються в комплексному підході до проблеми професійної готовності майбутніх учителів. Зазначений науковий підхід передбачає єдність соціального, психологічного i педагогічного; поєднує освітню, розвивальну й виховну функції навчання; забезпечує єдність усіх компонентів дидактичної системи навчання та професійної підготовки. Так, у представленій структурі професійно-педагогічної готовності цілісно поєднуються соціальні, психологічні та педагогічні чинники [11, с. 19]. У процесі формування цього системного утворення реалізовуються вищезазначені функції навчання, серед яких провідну роль відіграє розвивальна. Результатом упровадження моделі професійно-педагогічної підготовки як цілісної науково-методичної системи навчання стає формування професійної готовності майбутніх учителів до реалізації розвивальної функції навчання.

Акмеологічний підхід до підготовки майбутніх учителів, формування суб’єктів професійно-педагогічної діяльності акцентує увагу на особистісних якостях педагога: потреба в засвоєнні нового; системне мислення в опрацюванні моделей професійної діяльності; здібності до об’єктивної самооцінки професійної поведінки; висока мотивація досягнення в праці [5, с. 12-13]. У дослідженнях Н. Кузьміної акмеологічна модель педагога представляється на трьох рівнях: професійна зрілість - готовність педагога до інноваційної професійної діяльності; особистісна зрілість - самостійність і відповідальність за прийняті життєві та професійні рішення; духовна зрілість - життєва мудрість, творити добро, нести любов, що свідчить про духовний саморозвиток педагога [5, с. 14]. 
На нашу думку, професійна зрілість педагога визначається функціональним рівнем професійно-педагогічної готовності, особистісна зрілість - особистісним рівнем готовності, духовна зрілість є результатом цілісного формування професійно-педагогічної готовності, а також становлення педагога як суб’єкта життєдіяльності 3 високими моральними цінностями.

Реалізація компетентнісного підходу в професійній підготовці майбутніх учителів із основ здоров’я передбачає не засвоєння готової навчальної інформації, не передачу вмінь, а формування у студентів професійно-педагогічної компетентності. Професійно-педагогічна компетентність тісно пов'язується з готовністю до професійно-педагогічної діяльності як одного із провідних засобів та умов розвитку особистості педагога. Тому, на наш погляд, зміст професійно-педагогічної компетентності може бути розкритий через готовність до професійної педагогічної діяльності.

Готовність є однією із ключових якостей особистості, зумовлених її генетичними особливостями, соціально-психологічними властивостями й певним видом діяльності. Вона $є$ результатом підготовки (як процесу формування готовності) й пов’язується 3 тією діяльністю, що має виконуватися в майбутньому. Професійно-педагогічна готовність забезпечується педагогічними здібностями, культурою педагогічного спілкування, педагогічною спрямованістю й свідомістю, а також особливим педагогічним мисленням. Структура професійної готовності майбутніх учителів може бути представленою на двох рівнях: функціональному та особистісному. Обгрунтовано, що розв'язання проблеми професійної готовності майбутніх учителів до навчання учнів основам здоров’я передбачає застосування діяльнісного, системного, комплексного, особистісно зорієнтованого, антропологічного, культурологічного, акмеологічного та компетентнісного підходів до процесу професійно-педагогічної підготовки.

Предметом подальших наших досліджень є розкриття змісту професійно-педагогічної компетентності через готовність до професійної педагогічної діяльності, що реалізується на функціональному й особистісному рівнях і забезпечує саморозвиток педагогічної системи «вчитель - учень» («викладач - студент»).

\section{Література}

1. Выготский Л. С. Психология развития человека / Л. С. Выготский. - Москва : Эксмо, 2006. - 1135 с. 2. Зязюн І. А. Культура в контексті політики та освіти / І. А. Зязюн // Мистецтво та освіта. - 1998. - № 2. - С. 2-8. 3. Князева Е. Н. Синергетика как новое мировидение: диалог с И. Пригожиным / Е. Н. Князева, С. П. Курдюмов // Вопросы философии. - 1992. - № 2. - С. 3-20. 4. Кушнір В. А. Теоретико-методологічні основи системного аналізу педагогічного процесу вищої школи : дис. на здобуття наук. ступеня доктора пед. наук: 13.00.04/ Кушнір Василь Андрійович. - Кіровоград, 2003. - 491 с. 5. Максимова В. Н. Акмеология: новое качество образования: [книга для педагога]/ В. Н. Максимова. - Санкт-Петербург : РГПУ им. А. И. Герцена, 2002. - 99 с. 6. Методика навчання i наукових досліджень у вищій школі:[навч. посіб.] / С. У. Гончаренко, П. М. Олійник, В. К. Федорченко та ін. [ за ред. С. У. Гончаренка, П. М. Олійника]. - Київ : Вища школа, 2003. - 323 с. 7. Педагогіка вищої школи: [навч. посіб.] / [3. Н. Курлянд, Р. І. Хмелюк, А. В. Семенова та ін.]; за ред. 3. Н. Курлянд. - [3-тє вид., перероб. і доп.] Київ : Знання, 2007. - 495 с. 8. Роджерс К. Несколько важных открытий / К. Роджерс // Вестник МГУ. - Серия 14. Психология. - 1990. - № 2. - С. 58-65. 9. Рубинштейн С. Л. Принципы и пути развития психологии / С. Л. Рубинштейн. - Москва : АН СССР, 1959. 354 с. 10. Свириденко А. Ю. Становлення і розвиток основ безпеки життєдіяльності людини 
як навчальної дисципліни у контексті сучасної вітчизняної освіти / А. Ю. Свириденко // Матеріали Міжнар. наук.-практ. конф. «Ідеї К. Д. Ушинського в сучасній педагогіці» (м. Київ, 2014 р.). - С. 112-117. 11. Семенець Л. М. Формування професійної готовності майбутніх учителів до розвитку математичних здібностей у старшокласників: дис. на здобуття наук. ступеня канд. пед. наук : 13.00.04 / Семенець Лариса Миколаївна. - Житомир, 2013. -247 с. 12. Старіш О. Г. Системологія: [підручник] / Олександр Григорович Старіш. - Київ : ЦНЛ, 2005. - 232 с. 13. Талызина Н. Ф. Управление процессом усвоения знаний / Н. Ф. Талызина. М. : МГУ, 1975. - 343 с. 14. Штофф В. А. Моделирование и философия : [монография] / Виктор Александрович Штофф. - Москва - Ленинград : Наука, 1966. - 303 с.

УДК 373.51 .78

Віталій Смородський

\section{ОРГАНІЗАЦІЙНО-ПЕДАГОГІЧНІ УМОВИ ФОРМУВАННЯ ВИКОНАВСЬКИХ НАВИЧОК НА ЗАСАДАХ ЖАНРОВОГО ПІДХОДУ В УЧНІВ ДИТЯЧИХ МУЗИЧНИХ ШКІЛ}

Смородський В. I. Організаційно-педагогічні умови формування виконавських навичок на засадах жанрового підходу в учнів дитячих музичних шкіл.

У статті проаналізовано та розкрито методологічну сутність понять «педагогічні умови» та «організаційно-педагогічні умови». Визначено педагогічні умови формування виконавських навичок учнів дитячих музичних шкіл на основі жанрового підходу: формування мотиваційної спрямованості процесу навчання з оволодіння виконавськими навичками на основі жанрового підходу; вибір змісту, форми, методів та засобів формування виконавських навичок на основі жанрового підходу; налагодження діалогічного спілкування викладача та учня як основи формування виконавських навичок на основі жанрового підходу.

Ключові слова: виконавські навички, жанровий підхід у формуванні виконавських навичок в учнів дитячих музичних шкіл, педагогічні умови.

Смородский В. И. Организационно-педагогические условия формирования у учеников детских музыкальных школ исполнительских навыков на основе жанрового подхода.

В статье проанализирована и раскрыта методологическая суть понятий «педагогические условия» и «организационно-педагогические условия». Определены педагогические условия формирования исполнительских навыков учащихся детских музыкальных школ на основе жанрового подхода: формирование мотивационной направленности процесса обучения по овладению исполнительскими навыками на основе жанрового подхода; выбор содержания, форм, методов и средств формирования исполнительских навыков на основе жанрового подхода; налаживания диалогического общения преподавателя и ученика как основы формирования исполнительских навыков на основе жанрового подхода.

Ключевые слова: исполнительские навыки, жанровый подход в формировании исполнительских навыков у учащихся детских музыкальных школ, педагогические условия.

Smorodskyi V. I. Organizational and pedagogical conditions of performance skills formation of music schools pupils on the basis of genre approach.

In the article methodological meaning of the term «Pedagogical conditions» was analysed. 